\title{
CORRIGENDUM
}

\section{Allogeneic hematopoietic SCT for patients with autoimmune diseases}

T Daikeler, T Hügle, D Farge, M Andolina, F Gualandi, H Baldomero, C Bocelli-Tyndall, M Brune, JH Dalle, G Ehninger, B Gibson, B Linder, B Lioure, A Marmont, S Matthes-Martin, D Nachbaur, P Schuetz, A Tyndall, JM van Laar, P Veys, R Saccardi and A Gratwohl, on behalf of the Working Party Autoimmune Diseases of the EBMT

Bone Marrow Transplantation (2009) 44, 67; doi:10.1038/bmt.2009.118

Correction to: Bone Marrow Transplantation (2009) 44, 27-33; doi:10.1038/bmt.2008.424

Since the publication of their paper, the authors have noticed that one of the co-authors is not listed. C Urban, who is at the
Department of Haematology and Oncology at the Pediatric University Hospital Graz, Graz, Austria, should have been included as the tenth author in the author list above.

The authors would like to apologize for any inconvenience caused. 